\title{
Data quality of the routine health management information system at the primary healthcare facility and district levels in Tanzania
}

\section{SUSAN F. RUMISHA}

National Institute for Medical Research

EMANUEL P. LYIMO

National Institute for Medical Research

IRENE R. MREMI

National Institute for Medical Research

PATRICK K. TUNGU

National Institute for Medical Research, Amani Research Centre

VICTOR S. MWINGIRA

National Institute for Medical Research, Amani Research Centre

DORIS MBATA

National Institute for Medical Research

SIA E. MALEKIA

National Institute for Medical Research

CATHERINE JOACHIM

Ministry of Health, Community Development, Gender, Elderly and Children

Leonard Mboera ( $\nabla$ Imboera@gmail.com )

National Institute for Medical Research https://orcid.org/0000-0001-5746-3776

\section{Research}

Keywords: health information, data, quality, completeness, accuracy, facility, district, Tanzania

Posted Date: June 1st, 2020

DOI: https://doi.org/10.21203/rs.3.rs-31672/v1

License: (c) (1) This work is licensed under a Creative Commons Attribution 4.0 International License. Read Full License 


\section{Abstract \\ Background}

Effective planning for disease prevention and control requires accurate, adequately-analysed, interpreted and communicated data. This study assessed the quality of routine Health Management Information System (HMIS) data at healthcare facility (HF) and district levels in Tanzania.

\section{Methods}

HMIS tools used at primary health care facilities (dispensary, health centre, hospital) and district office were reviewed to assess their availability, completeness, and accuracy of collected data. The assessment involved seven health service areas namely, Outpatient department, Inpatient department, Antenatal care, Family Planning, Post-natal care, Labour and Delivery and Provider-initiated Testing and Counselling.

\section{Results}

A total of $115 \mathrm{HFs}$ in 11 districts were assessed. Registers (availability rate $=91.1 \%$; interquartile range (IQR):66.7\%-100\%) and report forms (86.9\%; IQR:62.2\%-100\%) were the most utilized tools. There was a limited use of tally-sheets (77.8\%; IQR:35.6\%-100\%). Tools availability at dispensary was $91.1 \%$, healthcentre $82.2 \%$ and hospital $77.8 \%$, and was poor in urban districts. The availability rate at the district level was 65\% (IQR:48\%-75\%). Reports were highly over-represented in comparison to registers' records, with large differences observed at HF phase of the data journey and more profound in hospitals. Tool availability and data quality varied by service-areas, indicators, facility level, and districts, however, with a remarkable improvement over the years.

\section{Conclusion}

There are high variations and improvements in the tool utilisation and data accuracy at facility and district levels. The routine HMIS is weak and data at district level inaccurately reflects what is available at the HFs. These results highlight the need to design tailored and inter-service strategies for improving data quality.

\section{Background}

Disease prevention and control requires prompt and adequate actions towards reduction or elimination of existing conditions, and preventing new occurrences. Efficient decisions to such actions should be based on correctly collected, analysed, interpreted, and, timely data. In low- and middle-income countries, data for decision-making are generated by the health information systems (HISs), mostly through the routine Health Management Information System (HMIS) [1]. HMIS integrates data collection, processing, reporting and facilitates use at all levels to improve health service effectiveness and efficiency in response [1, 2]. 
HMIS collects data at health facilities (HFs), which contains statistics on health services, disease epidemiology, and administration [3]. Quality information is essential to monitor, evaluate, prioritize, and improve the delivery of health care services $[1,2,4]$.

Studies in Sub-Saharan Africa (SSA) have reported challenges with data quality, including poor utilization of HMIS tools, incomplete recording, inconsistency, inaccuracy and untimely reporting [1, 5-13]. The concerns about the quality of routine information have undermined data utilization for decision-making in the health sector $[9,10,14,15]$. Challenges in data quality in SSA are compounded by human, health system (HS) and infrastructure factors $[1,2,16]$. Healthcare workers face a poor understanding of HMIS tools and the variables/indicators, inadequate skills, workload, and lack of incentives $[9,11,13]$. Excessive data demand, large number of reports, frequent changes in HMIS tools, changes in organisation structures or of human resource, lack of effective systems to monitor quality and absence of standards guidance to measure data quality contribute to poor quality $[16,17]$. Limited infrastructure and means to transmit reports from one level to another add more complexity $[5,14,17-19]$. Data quality assessments need to address these attributes and processes to establish valid conclusions that foster solution-focused thinking $[15,16]$.

Weak health information systems in SSA are critical challenges to reaching the global and national health goals because the health system performance cannot be adequately monitored where data are of poor quality $[2,10]$. It is evident that increased investment in health is dependent on an efficient and reliable HMIS. With the current massive investment in disease control, availability of quality information is critical. Evidences suggest a lack of data quality in the Tanzania HMIS [9, 20-22]; and of recently, no robust assessment and analysis at primary health care levels has been done. This study assessed data quality of the routine HMIS at primary health care facility and district levels in Tanzania to determine attribute-based differentiation of quality levels and propose strategies for improvement.

\section{Methods}

\section{Study design}

This cross-sectional study was carried out from October-November 2017 and involved 11 districts and all levels of primary health care facilities (i.e. dispensary, health centre, and hospital) in Tanzania. A multistage sampling technique was used to randomly select 1-2 regions from each geographical zone [23] and one district from each region of Tanzania. District hospitals were conveniently included (regional hospital taken where there was no district hospital). At least $50 \%$ of the health centres $(\mathrm{HC})$ with a minimum-maximum criterion of $2-4$, and $20 \%$ of dispensaries (min-max of $5-8$ ) were randomly selected.

\section{Data sources}

The study involved reviews of documents, systems and databases and collection of primary data at facility and district levels. The source of data included facility level registers, tally sheets and monthly summary reports (paper and electronic). The sources of data included HF registers, tally-sheets, and 
monthly reports (paper and electronic). Seven service areas namely Outpatient department (OPD), Inpatient department (IPD), Antenatal care (ANC), Family Planning (FP), Post-natal care (PNC), Labour and Delivery (LnD) and Provider-Initiated Testing and Counselling (PITC) were included in the assessment. A total of 34 indicators selected from each of the service area $(O P D=5 ; I P D=4 ; A N C=8 ; P N C=6 ; \operatorname{LnD}=2$; $\mathrm{FP}=6 ; \mathrm{PITC}=3$ ) were assessed. The selected indictors included those that were easy to collect, difficult to understand, difficult to compile, and takes time to compile.

The team for each district comprised of four trained research assistants under supervision of two senior researchers. Training was done before actual data collection and involved pilot exercise to ensure clarity on the HMIS tools (registers, tally sheets and reporting forms) and how they are supposed to be used, type of data to be collected, ethical issues when dealing with patient information.

\section{Data collection procedures}

The assessment exercise considered and tracked data based on the order of events in the existing HMIS (referred in this context as "data journey"). Primarily, patient data are recorded in registers at the time a client is been attended. The records are compiled at the end of each month to make a report, done in duplicate and separately for each service unit. Tally sheets, designed for each service unit with the same structure as the reported indicators, are used daily to track each record. The original month report is submitted to the district office. Used registers, tally sheets and carbon copies of all reports are kept/stored at the facility for their use and future reference. The reports submitted to the district office are expected to be filed and organized and the data is later entered in the electronic system for further analysis and use.

At the facility, records of each indicator were tracked across all sources, i.e. physical counts from registers, records marked in tally-sheets and compiled totals in report forms. At the district health office, original copies of monthly report forms submitted by facilities were reviewed. The filled records were compared to those observed in the carbon copies of reports (found at the facility), and to what has been entered in the electronic system, known as District Health Information System-2 (DHIS2). The period of data assessment covered 4 years, January 2014 to September 2017 (45 months) with a detailed review covering 12 months. To select months for the detailed review, we fixed the last quarter of 2014 (October-December) and the first quarter of 2017 (January-March) (providing maximum time to resolve existing data issues). Then we conveniently assigned April-June 2016 and July-September 2015 to get an equal time interval (6 months) between the quarters.

\section{Definition of indicators}

At the facility level, tools availability was defined as the presence of filled/used HMIS tools (registers/tallysheets/report forms by service area). At the district office, we tracked report forms from the health facilities for the selected 12 months. This tracking aimed to establish the fact that patient records were filled, tallysheets were utilized, reports were compiled and submitted to the district office each month. The availability rate at the facility level was calculated as the percentage of observed registers/tally-sheets/report out of those expected in a specified period. The availability rate at district level was used to measure reporting completeness (percentage of reports received from HFs in a specified period). Completeness focused on 
recording by reviewing filling practices of registers compared to the provided instructions. Accuracy measured the numerical correspondence between data reported in one tool (subsequent) and that appearing in the original source.

\section{Data Management}

Data entry was done in EpiData 3.1 (EpiData Association, Odense M, Denmark), then data migrated to STATA 13 (STATA, College Station, TX) for analysis. We assessed data quality by year, service area, indicators, tool, facility level, ownership and district. Based on total expected register-months, tally sheetmonths and monthly reports, we calculated the median availability rates and the interquartile range (IQR). For the IQR we presented the 25th and 75th percentiles, and range (p75-p25) to assess variability in performance.

For accuracy, we calculated a difference ratio (DR), an index measure that quantifies the difference between data sources $[8,15,24]$. Six DR indices, Diff1-6, were calculated and assessed, and grouped considering the three phases of the data journey, i.e. from the point a record entered a register at the facility to the point it reaches the DHIS2. The "health facility phase" focused on data activities occurring at the healthcare facility (recording to report compilation). The "transmission phase", focused on report processing and communication (facility-district, district files-DHIS2) accounting for the revisions/corrections happening during this process. The "robust phase" compared data recounted from registers with totals entered in the DHIS2. With this phase, we present an ideal situation where all quality issues at the facility or during transmission are masked and data of the two extreme ends of the data journey is compared. This categorization facilitates systematic understanding, tagging quality issues and explore mechanisms to design practical-oriented data quality interventions stage wise.

$\mathrm{DR}<1$ indicates fewer data in the subsequent source, implying under-representation. $\mathrm{DR}>1$ means more data in the subsequent source, implying over-representation, while $D R \approx 1$ implying consistency between sources. Matching levels were categorized into 5 groups (depending on the increase/decrease from $D R=$ 1 ) and presented using colour-coded tables by different attributes. These were: (i) matched: $0.95 \leq \mathrm{DR} \leq$ 1.05 , i.e. acceptable difference $\pm 5 \%$; (ii) moderately under-represented: $0.75 \leq \mathrm{DR}<0.95$ or moderately over-represented: $1.05<\mathrm{DR} \leq 1.25$; (iii) under-represented: $0.5<\mathrm{DR} \leq 0.75$ or over-represented: $1.25<\mathrm{DR} \leq$ 1.5; (iv) highly under-represented: DR $<0.5$ or highly over-represented: $1.5<D R \leq 2$; and, (v) extremely overrepresented: $D R>2$. Statistical significance was tested using t-tests and proportional tests, significance considered at $\mathrm{p}$-value $<0.05$.

\section{Results}

\section{Tools availability}

A total of 115 healthcare facilities (HFs) in 11 districts were assessed. Both urban and rural districts were included in the study. Urban districts were Dodoma, Igunga, Kahama, Kinondoni, and Njombe. Rural districts were Hai, Kibaha, Mbinga, Mbulu, Nkasi and Tandahimba. Igunga and Dodoma had no district 
hospitals, therefore, the respective regional hospitals were included. Of the $115 \mathrm{HFs}, 58.3 \%(n=67)$ were dispensaries, $31.3 \%(n=36)$ health centres and $10.4 \%(n=12)$ hospitals. Of all the HFs, 114 had OPD, IPD (43), ANC (108), PNC (105), PITC (94), LnD (93) and FP (88) service-areas.

The overall median availability rate for registers was $91.1 \%$ (IQR:66.7\%,100\%) compared to $77.8 \%$ (IQR:35.6\%, 100\%) and 86.9\% (IQR: 62.2\%,100\%) for the tally-sheets and report forms, respectively (Table 1). HMIS tools were mostly available at the dispensaries $91.1 \%$ (IQR:60\%,100\%) than health centres 82.2\% (IQR: $55.6 \%, 100 \%$ ) and hospitals 77.8\% (IQR:30\%, 97.8\%) (p-value < 0.0001). Faith-based owned facilities had a significantly higher amount of tools available than the government- and private-owned facilities ( $p$-value $<0.0001$ ). The service-areas with high tool availability rates were ANC $95.6 \%$ (IQR:73.3\%,100\%), FP 93.3\% (IQR:66.7\%,100\%) and LnD 91.1\% (IQR:73.3\%,100\%). PITC had the lowest rate 53.3\% (IQR:20\%,88.9\%). Hai, Kibaha, Mbinga, Mbulu had the highest availability rates while Kinondoni and Dodoma had the lowest levels (Table 1 ). 
Table 1

Status of overall HMIS tool availability rates at HF by different attributes

\begin{tabular}{|c|c|c|c|c|c|}
\hline Variable & Categories & Median & IQR (p25,p75) & Range & P-value \\
\hline \multirow[t]{3}{*}{ All years } & Registers & $91 \cdot 1 \%$ & $(66 \cdot 7,100)$ & $33 \%$ & $<0.001$ \\
\hline & Report forms & $86 \cdot 7 \%$ & $(62 \cdot 2,100)$ & $38 \%$ & \\
\hline & Tally-sheets & $77 \cdot 8 \%$ & $(35 \cdot 6,100)$ & $64 \%$ & \\
\hline \multirow[t]{4}{*}{2014} & Overall & $83 \cdot 3 \%$ & $(0,100)$ & $100 \%$ & \\
\hline & Registers & $91 \cdot 7 \%$ & $(16 \cdot 7,100)$ & $83 \%$ & \\
\hline & Report forms & $75 \cdot 0 \%$ & $(0,100)$ & $100 \%$ & \\
\hline & Tally-sheets & $41 \cdot 7 \%$ & $(0,100)$ & $100 \%$ & \\
\hline \multirow[t]{4}{*}{2015} & Overall & $100 \cdot 0 \%$ & $(50,100)$ & $50 \%$ & \\
\hline & Registers & $100 \cdot 0 \%$ & $(75,100)$ & $25 \%$ & $<0.001$ \\
\hline & Report forms & $100 \cdot 0 \%$ & $(75,100)$ & $25 \%$ & \\
\hline & Tally-sheets & $100 \cdot 0 \%$ & $(16 \cdot 7,100)$ & $83 \%$ & \\
\hline \multirow[t]{4}{*}{2016} & Overall & $100 \cdot 0 \%$ & $(83 \cdot 3,100)$ & $17 \%$ & \\
\hline & Registers & $100 \cdot 0 \%$ & $(91 \cdot 7,100)$ & $8 \%$ & \\
\hline & Report forms & $100 \cdot 0 \%$ & $(91 \cdot 7,100)$ & $8 \%$ & \\
\hline & Tally-sheets & $100 \cdot 0 \%$ & $(33 \cdot 3,100)$ & $67 \%$ & \\
\hline \multirow[t]{4}{*}{2017} & Overall & $100 \cdot 0 \%$ & $(77 \cdot 8,100)$ & $22 \%$ & \\
\hline & Registers & $100 \cdot 0 \%$ & $(88 \cdot 9,100)$ & $11 \%$ & \\
\hline & Report forms & $100 \cdot 0 \%$ & $(77 \cdot 8,100)$ & $22 \%$ & \\
\hline & Tally-sheets & $100 \cdot 0 \%$ & $(55 \cdot 6,100)$ & $44 \%$ & \\
\hline \multirow[t]{3}{*}{ Facility level } & Dispensary & $91 \cdot 1 \%$ & $(60,100)$ & $40 \%$ & $<0.001$ \\
\hline & Health Centre & $82 \cdot 2 \%$ & $(55 \cdot 6,100)$ & $44 \%$ & \\
\hline & Hospital & $77 \cdot 8 \%$ & $(30,97 \cdot 8)$ & $68 \%$ & \\
\hline \multirow[t]{3}{*}{ Facility Ownership } & Faith-based Organization & $91 \cdot 1 \%$ & $(68 \cdot 9,100)$ & $31 \%$ & $<0.001$ \\
\hline & Government & $86 \cdot 7 \%$ & $(60,100)$ & $40 \%$ & \\
\hline & Private & $68 \cdot 9 \%$ & $(20,95 \cdot 6)$ & $76 \%$ & \\
\hline \multirow[t]{2}{*}{ Service area } & Antenatal care & $95 \cdot 6 \%$ & $(73 \cdot 3,100)$ & $27 \%$ & $<0.001$ \\
\hline & Family planning & $93 \cdot 3 \%$ & $(66 \cdot 7,100)$ & $33 \%$ & \\
\hline
\end{tabular}




\begin{tabular}{|c|c|c|c|c|c|}
\hline \multirow[t]{6}{*}{ Variable } & Categories & Median & IQR (p25,p75) & Range & P-value \\
\hline & Inpatient & $77 \cdot 8 \%$ & $(44 \cdot 4,100)$ & $56 \%$ & \\
\hline & Labour and Delivery & $91 \cdot 1 \%$ & $(73 \cdot 3,100)$ & $27 \%$ & \\
\hline & Outpatient & $83 \cdot 3 \%$ & $(57 \cdot 8,100)$ & $42 \%$ & \\
\hline & PITC & $53 \cdot 3 \%$ & $(20,88 \cdot 9)$ & $69 \%$ & \\
\hline & Post-natal care & $77 \cdot 8 \%$ & $(46 \cdot 7,97 \cdot 8)$ & $51 \%$ & \\
\hline \multirow[t]{11}{*}{ District } & Dodoma & $60 \cdot 0 \%$ & $(24 \cdot 4,88 \cdot 9)$ & $64 \%$ & $<0.001$ \\
\hline & Hai & $97 \cdot 8 \%$ & $(71 \cdot 1,100)$ & $29 \%$ & \\
\hline & Igunga & $87 \cdot 8 \%$ & $(66 \cdot 7,100)$ & $33 \%$ & \\
\hline & Kahama & $80 \cdot 0 \%$ & $(55 \cdot 6,100)$ & $44 \%$ & \\
\hline & Kibaha & $93 \cdot 3 \%$ & $(77 \cdot 8,91 \cdot 1)$ & $13 \%$ & \\
\hline & Kinondoni & $46 \cdot 7 \%$ & $(22 \cdot 2,80)$ & $58 \%$ & \\
\hline & Mbinga & $95 \cdot 6 \%$ & $(75 \cdot 6,100)$ & $24 \%$ & \\
\hline & Mbulu & $100 \cdot 0 \%$ & $(91 \cdot 1,100)$ & $9 \%$ & \\
\hline & Njombe & $88.9 \%$ & $(71 \cdot 1,100)$ & $29 \%$ & \\
\hline & Nkasi & $78.9 \%$ & $(66 \cdot 7,97 \cdot 8)$ & $31 \%$ & \\
\hline & Tandahimba & $88.9 \%$ & $(60,100)$ & $40 \%$ & \\
\hline
\end{tabular}

High variation in the range value was observed in tally-sheet indicating a significant difference in its utilisation between facilities. A remarkable increasing trend in the availability of tools with lesser variation between HFs was observed from 2014 (median $=83.3 \%$; range $=100 \%$ ) to 2017 (median $=100 \%$; range $=$ 22\%) (Table 1, Fig. 1).

In terms of availability of tools, we categorised HFs into 4 groups: (i) $>75 \%-100 \%$ (very high); (ii) $50 \%-75 \%$ (high); (iii) 25\%-50\% (average); and (iv) < 25\% (low). In all service-areas, with exception of PITC, over 50\% of the facilities were able to locate up to $>75 \%$ of the required registers (Fig. 2), with high percentages observed in ANC (82.4\%), OPD (74.6\%), LnD (73.1\%) and FP (72.7\%). PITC registers were rarely available with only $45 \%$ of the facilities been able to locate $>75 \%$. Over $15 \%$ of the facilities presented less than $25 \%$ of the expected PITC registers followed by PNC service-area (11.4\%).

Tally-sheets for ANC, LnD, and FP were available in larger proportions than those for IPD, OPD, and PNC (Fig. 3). Report forms were highly available in all service-areas except for PITC which had $42.1 \%$ of 
facilities providing $\leq 25 \%$ of expected report forms. Urban districts of Igunga, Kibaha, Njombe, Kinondoni, and Tandahimba fell into average or low categories of availability particularly on tally-sheets.

At the district office, the overall median availability of submitted HF reports was 65\% (IQR:48\%,75\%) indicating that a third of expected report forms were not found. District-specific performance indicated that less than half of the expected reports were found in the urban districts of Dodoma (median $=45 \%$, IQR:25\%,51\%) and Kinondoni (median $=46 \%$, IQR: 41\%-50\%) (Fig. 4). Rural districts had higher rates: Hai (75\%, IQR:67\%,82\%), Igunga (74\%, IQR:56\%,81\%), Mbinga (73\%, IQR:67\%,76\%), Nkasi (72\%, IQR:66\%,81\%), and Mbulu (71\%, IQR:71\%,86\%). Overall, higher availability rates were observed at HF than at district level with variations between service areas and HFs.

In most districts, there was an increase in the availability of report forms over the years. However, the availability rate in the urban districts of Dodoma, Kibaha, Kinondoni and Njombe remained low during the period under review (Fig. 5).

\section{Completeness}

Wrongly filled or empty cells in HF registers were common. Diagnoses were either not recorded or recorded without indicating disease severity (as instructed) or without laboratory results when available. This was common for malaria and anaemia. In OPD registers, it was a common practice for patient' height and weight variables to be left blank, and occasionally sex and age were not filled.

Poor adherence to the coding procedures was frequent. For instance, instead of using " $\mathrm{N}-\mathrm{Ndio}$ " and " $\mathrm{H}$ Hapana" (Kiswahili words for "Yes" and "No", respectively), several records were in the English version of the words " $\mathrm{Y}$-Yes" and " $\mathrm{N}-\mathrm{No}^{\prime}$ ". In other situations, instead of using a "tick" mark as instructed when the service was provided, a recorder would use " $\mathrm{N}$ " or " $\mathrm{X}$ ", or leave the entries blank or use a different code that meant a different thing altogether. Consequently, this resulted into changing the meaning of that particular record. In some cases, health workers couldn't remember what the codes used meant. Such practices were reported to complicate compilation of the report, especially if a different person (from the one who did the record) is compiling the report.

Improper use of carbon papers was observed in HFs. In some instances, it was hard to identify the value recorded in the report form. The use of worn-out carbon papers was common and resulted into a blank or very faint report copies. Such poor recording practices led to differences between recounted and reported data hence low accuracy performance.

\section{Data accuracy}

ANC service. At the HF phase, Diff1 indicates over $50 \%$ representation of data in tally-sheets while Diff2 shows extreme over-representation (of close to 3-folds) in the reports compared to registers' records. A similar pattern was observed for Diff6 when registers counts were compared to the DHIS2 records. The transmission phase indicated consistency. The slight difference between Diff2 and Diff6 (with stable Diff3-Diff5) suggests that the reports transmitted to the district were slightly manipulated 
(corrected/revised) before entered into the DHIS2, yet the changes were not documented. The overrepresentation levels decreased slightly over the years (Table 2).

Table 2

Data accuracy as indicated by difference ratio for the antenatal care service area

\begin{tabular}{|c|c|c|c|c|c|c|c|}
\hline \multirow[t]{3}{*}{ Year } & \multirow[t]{3}{*}{ Month } & \multicolumn{2}{|c|}{ Health facility phase } & \multicolumn{3}{|c|}{ Transmission phase } & \multirow{3}{*}{$\begin{array}{l}\text { Robust } \\
\text { Diff } 6 \\
\text { DHIS2 } \\
\text { vs. } \\
\text { Registers }\end{array}$} \\
\hline & & Diff 1 & Diff 2 & Diff 3 & Diff 4 & Diff 5 & \\
\hline & & $\begin{array}{l}\text { Tally vs. } \\
\text { Registers }\end{array}$ & $\begin{array}{l}\text { Report } \\
\text { (Facility) } \\
\text { vs. } \\
\text { Registers }\end{array}$ & $\begin{array}{l}\text { Report } \\
\text { (District) vs. } \\
\text { Report } \\
\text { (Facility) }\end{array}$ & $\begin{array}{l}\text { DHIS2 } \\
\text { vs. } \\
\text { Report } \\
\text { (Facility) }\end{array}$ & $\begin{array}{l}\text { DHIS2 } \\
\text { VS. } \\
\text { Report } \\
\text { (District) }\end{array}$ & \\
\hline \multirow[t]{3}{*}{2014} & Oct & $1 \cdot 11$ & $1 \cdot 74$ & $1 \cdot 07$ & $1 \cdot 04$ & 0.98 & $1 \cdot 84$ \\
\hline & Nov & $1 \cdot 58$ & $2 \cdot 70$ & 0.99 & 0.96 & 0.94 & $2 \cdot 12$ \\
\hline & Dec & $1 \cdot 80$ & $2 \cdot 98$ & $1 \cdot 01$ & 0.96 & 0.98 & $2 \cdot 25$ \\
\hline \multirow[t]{3}{*}{2015} & July & $1 \cdot 36$ & $1 \cdot 53$ & $1 \cdot 02$ & $1 \cdot 00$ & $1 \cdot 01$ & $1 \cdot 33$ \\
\hline & Aug & $1 \cdot 75$ & $2 \cdot 50$ & $1 \cdot 03$ & $1 \cdot 14$ & $1 \cdot 13$ & $2 \cdot 22$ \\
\hline & Sept & $1 \cdot 37$ & $1 \cdot 66$ & $1 \cdot 00$ & $1 \cdot 00$ & $1 \cdot 01$ & $1 \cdot 50$ \\
\hline \multirow[t]{3}{*}{2016} & Apr & $1 \cdot 47$ & $1 \cdot 81$ & $1 \cdot 05$ & $1 \cdot 08$ & $1 \cdot 08$ & $1 \cdot 57$ \\
\hline & May & $1 \cdot 36$ & $2 \cdot 03$ & 0.98 & $1 \cdot 13$ & $1 \cdot 11$ & $1 \cdot 97$ \\
\hline & Jun & $1 \cdot 29$ & $1 \cdot 53$ & $1 \cdot 03$ & $1 \cdot 02$ & 0.99 & $1 \cdot 31$ \\
\hline \multirow[t]{3}{*}{2017} & Jan & $1 \cdot 66$ & $1 \cdot 83$ & $1 \cdot 06$ & $1 \cdot 04$ & 0.98 & $1 \cdot 57$ \\
\hline & Feb & $1 \cdot 82$ & $2 \cdot 13$ & $1 \cdot 03$ & $1 \cdot 03$ & $1 \cdot 03$ & $1 \cdot 86$ \\
\hline & March & 1.33 & $1 \cdot 53$ & 1.02 & 1.02 & 1.00 & $1 \cdot 33$ \\
\hline
\end{tabular}

\begin{tabular}{|llll}
$\begin{array}{l}\geq 0.95- \\
1.05\end{array}$ & Matched & $\begin{array}{l}>1.05- \\
1.25\end{array}$ & $\begin{array}{l}\text { Moderately } \\
\text { over- } \\
\text { represented }\end{array}$ \\
\hline $\begin{array}{l}<0.95- \\
0.75\end{array}$ & $\begin{array}{l}\text { Moderately } \\
\text { under- } \\
\text { represented }\end{array}$ & $>1 \cdot 25-1.5$ & $\begin{array}{l}\text { Over- } \\
\text { represented }\end{array}$ \\
\hline $\begin{array}{l}<0.75- \\
0.5\end{array}$ & $\begin{array}{l}\text { Under- } \\
\text { represented }\end{array}$ & $>1 \cdot 5-2$ & $\begin{array}{l}\text { Highly } \\
\text { over- } \\
\text { represented }\end{array}$ \\
\hline$<0.5$ & $\begin{array}{l}\text { Highly } \\
\text { under- } \\
\text { represented }\end{array}$ & $>2$ & $\begin{array}{l}\text { Extremely } \\
\text { over- } \\
\text { represented }\end{array}$ \\
\hline
\end{tabular}


The indicators for provision of tetanus vaccine (TT2) and malaria intermittent preventive treatment (IPT2) performed badly with lower registration than what had been tallied ( $>2$-folds), compiled, and reported ( $>3-$ folds). This implies the intensive marking of clients in tally-sheets without registration. Indicators on gestation age and HIV testing for pregnant women were moderately over-represented in tally-sheets and reports. The indicator for HIV testing for pregnant women $<25$ years old was highly under-represented in all phases, Diff1 $=0.31$, Diff4 $=0.14$; Diff5 $=0.16$ and Diff6 $=0.03$. Data were found in registers but not reflected in the tally-sheets or report forms or DHIS2. There was variation in the ANC performance by districts in Diff1, Diff2, and Diff6 with over-representation much higher in Mbulu, Kinondoni, Kahama, and Nkasi districts.

Labour and Delivery service. At HF level there was over-representation of data in the tally-sheets and reports as compared to what was recorded in the registers. At the transmission phase in 2016, there was over-representation of data in the district report as compared to the copy available at the facilities indicating that the reports were not comparable. There was no significant difference between Diff 2 and Diff6. The Diff6 values decreased over time indicating improvement in the data accuracy (Table 3). The first indicator had good matching levels at HF phase. However, it was found to be revised at transmission phase of which more records were seen in the district copy than in HF copies (source), DR $=1.31$. For the 2nd LnD indicator, few data were observed in the registers than tally-sheets or report. Although a large number of clients were indicated to deliver at HF as marked in the tally sheet almost none were marked of who assisted in delivery. The values in a report for this period (for the 2 nd indicator) matched those of who delivered at HF. There was little variation on the data quality performance by district on LnD. 
Table 3

Data accuracy as indicated by difference ratio for the labour and delivery service area

\begin{tabular}{|c|c|c|c|c|c|c|c|}
\hline \multirow[t]{3}{*}{ Year } & \multirow[t]{3}{*}{ Month } & \multicolumn{2}{|c|}{ Health facility phase } & \multicolumn{3}{|c|}{ Transmission phase } & \multirow{3}{*}{$\begin{array}{l}\text { Robust } \\
\text { Diff } 6 \\
\text { DHIS2 } \\
\text { vs. } \\
\text { Registers }\end{array}$} \\
\hline & & Diff 1 & Diff 2 & Diff 3 & Diff 4 & Diff 5 & \\
\hline & & $\begin{array}{l}\text { Tally vs. } \\
\text { Registers }\end{array}$ & $\begin{array}{l}\text { Report } \\
\text { (Facility) } \\
\text { vs. } \\
\text { Registers }\end{array}$ & $\begin{array}{l}\text { Report } \\
\text { (District) } \\
\text { vs. } \\
\text { Report } \\
\text { (Facility) }\end{array}$ & $\begin{array}{l}\text { DHIS2 } \\
\text { vs. } \\
\text { Report } \\
\text { (Facility) }\end{array}$ & $\begin{array}{l}\text { DHIS2 } \\
\text { vs. } \\
\text { Report } \\
\text { (District) }\end{array}$ & \\
\hline \multirow[t]{3}{*}{2014} & Oct & $2 \cdot 06$ & $2 \cdot 71$ & $1 \cdot 25$ & $1 \cdot 21$ & 0.98 & $2 \cdot 41$ \\
\hline & Nov & $1 \cdot 13$ & $1 \cdot 62$ & 0.97 & 0.99 & 1.00 & 1.57 \\
\hline & Dec & $1 \cdot 28$ & $1 \cdot 68$ & 0.98 & $1 \cdot 02$ & $1 \cdot 01$ & $1 \cdot 73$ \\
\hline \multirow[t]{3}{*}{2015} & July & $1 \cdot 19$ & $1 \cdot 39$ & 0.97 & $1 \cdot 05$ & $1 \cdot 06$ & $1 \cdot 37$ \\
\hline & Aug & $1 \cdot 20$ & $1 \cdot 25$ & $1 \cdot 02$ & $1 \cdot 12$ & $1 \cdot 09$ & $1 \cdot 32$ \\
\hline & Sept & $1 \cdot 10$ & $1 \cdot 21$ & $1 \cdot 00$ & $1 \cdot 19$ & $1 \cdot 10$ & $1 \cdot 35$ \\
\hline \multirow[t]{3}{*}{2016} & Apr & $1 \cdot 28$ & $1 \cdot 38$ & $1 \cdot 00$ & 0.98 & 0.98 & $1 \cdot 40$ \\
\hline & May & $1 \cdot 14$ & $1 \cdot 19$ & $1 \cdot 27$ & $1 \cdot 25$ & 0.99 & $1 \cdot 22$ \\
\hline & Jun & $1 \cdot 08$ & $1 \cdot 16$ & $2 \cdot 62$ & $1 \cdot 80$ & 0.99 & $1 \cdot 18$ \\
\hline \multirow[t]{3}{*}{2017} & Jan & $1 \cdot 28$ & $1 \cdot 29$ & $1 \cdot 26$ & 0.99 & 0.98 & $1 \cdot 31$ \\
\hline & Feb & $1 \cdot 28$ & $1 \cdot 25$ & 0.99 & 0.97 & $1 \cdot 05$ & $1 \cdot 20$ \\
\hline & March & $1 \cdot 28$ & $1 \cdot 31$ & 1.09 & $1 \cdot 09$ & $1 \cdot 00$ & $1 \cdot 26$ \\
\hline Key & & & & & & & \\
\hline
\end{tabular}

\begin{tabular}{|llll}
$\begin{array}{l}\geq 0.95- \\
1.05\end{array}$ & Matched & $\begin{array}{l}>1.05- \\
1.25\end{array}$ & $\begin{array}{l}\text { Moderately } \\
\text { over- } \\
\text { represented }\end{array}$ \\
\hline $\begin{array}{l}<0.95- \\
0.75\end{array}$ & $\begin{array}{l}\text { Moderately } \\
\text { under- } \\
\text { represented }\end{array}$ & $>1 \cdot 25-1.5$ & $\begin{array}{l}\text { Over- } \\
\text { represented }\end{array}$ \\
\hline $\begin{array}{l}<0.75- \\
0.5\end{array}$ & $\begin{array}{l}\text { Under- } \\
\text { represented }\end{array}$ & $>1 \cdot 5-2$ & $\begin{array}{l}\text { Highly } \\
\text { over- } \\
\text { represented }\end{array}$ \\
\hline$<0.5$ & $\begin{array}{l}\text { Highly } \\
\text { under- } \\
\text { represented }\end{array}$ & $>2$ & $\begin{array}{l}\text { Extremely } \\
\text { over- } \\
\text { represented }\end{array}$ \\
\hline
\end{tabular}

Post-natal service. For the PNC, the quality of data, especially in the filling of tally-sheets and compilation, improved significantly over the years. The results indicated that sometimes the data journey was not 
followed hence resulting in larger DR at report/register (Diff2) than tally sheet/register (Diff1). Diff2 and Diff6 were very similar indicating that data management at transmission phase does not influence the quality of PNC data (Table 4). Although about half of postnatal indicators performed well in Diff1, there were variations in Diff2. The first indicator (attendance within 48 hours), had moderate over-representation for Diff1. However, data were extremely over-represented in report forms compared to data entered in the registers. These findings indicate that tally-sheets captured more attendees than those recorded in the registers (Diff1 $=1.30$ ). The Diff2 of 3.09 implied that registers had less data compared to what was included in summary reports. This indicates that reports were not filled using data from the tally-sheets and in most cases were not recorded in the registers but summed up in the reports. District performance in PNC differed highly in Diff2 and Diff6. Health workers reported some of the PNC registers and indicators to be difficult to understand. 
Table 4

Data accuracy as indicated by difference ratio for the post-natal care service area

\begin{tabular}{|c|c|c|c|c|c|c|c|}
\hline \multirow[t]{3}{*}{ Year } & \multirow[t]{3}{*}{ Month } & \multicolumn{2}{|c|}{ Health facility phase } & \multicolumn{3}{|c|}{ Transmission phase } & \multirow{3}{*}{$\begin{array}{l}\text { Robust } \\
\text { Diff } 6 \\
\text { DHIS2 } \\
\text { vs. } \\
\text { Registers }\end{array}$} \\
\hline & & Diff 1 & Diff 2 & Diff 3 & Diff 4 & Diff 5 & \\
\hline & & $\begin{array}{l}\text { Tally vs. } \\
\text { Registers }\end{array}$ & $\begin{array}{l}\text { Report } \\
\text { (Facility) } \\
\text { vs. } \\
\text { Registers }\end{array}$ & $\begin{array}{l}\text { Report } \\
\text { (District) } \\
\text { vs. } \\
\text { Report } \\
\text { (Facility) }\end{array}$ & $\begin{array}{l}\text { DHIS2 } \\
\text { vs. } \\
\text { Report } \\
\text { (Facility) }\end{array}$ & $\begin{array}{l}\text { DHIS2 } \\
\text { Vs. } \\
\text { Report } \\
\text { (District) }\end{array}$ & \\
\hline \multirow[t]{3}{*}{2014} & Oct & $1 \cdot 35$ & 1.51 & 0.99 & 0.91 & 0.90 & $1 \cdot 37$ \\
\hline & Nov & $1 \cdot 87$ & $6 \cdot 48$ & $1 \cdot 11$ & 0.97 & 0.98 & $5 \cdot 30$ \\
\hline & Dec & $1 \cdot 25$ & $1 \cdot 37$ & 0.95 & $1 \cdot 13$ & 0.92 & $1 \cdot 38$ \\
\hline \multirow[t]{3}{*}{2015} & July & $1 \cdot 24$ & $1 \cdot 85$ & 0.93 & $1 \cdot 19$ & 0.96 & $2 \cdot 17$ \\
\hline & Aug & 0.95 & $1 \cdot 70$ & $1 \cdot 00$ & $1 \cdot 11$ & $1 \cdot 09$ & $1 \cdot 87$ \\
\hline & Sept & $1 \cdot 42$ & $1 \cdot 35$ & $1 \cdot 02$ & 0.98 & 0.91 & $1 \cdot 31$ \\
\hline \multirow[t]{3}{*}{2016} & Apr & $1 \cdot 23$ & $1 \cdot 46$ & $1 \cdot 06$ & $1 \cdot 03$ & 0.95 & $1 \cdot 43$ \\
\hline & May & $1 \cdot 31$ & $2 \cdot 43$ & $1 \cdot 00$ & $1 \cdot 26$ & $1 \cdot 28$ & $1 \cdot 88$ \\
\hline & Jun & $1 \cdot 01$ & $1 \cdot 57$ & 0.97 & 0.95 & $1 \cdot 00$ & $1 \cdot 56$ \\
\hline \multirow[t]{3}{*}{2017} & Jan & $1 \cdot 04$ & $1 \cdot 32$ & $1 \cdot 05$ & 0.98 & $1 \cdot 07$ & $1 \cdot 20$ \\
\hline & Feb & $1 \cdot 00$ & $1 \cdot 27$ & 0.94 & 0.98 & $1 \cdot 04$ & $1 \cdot 11$ \\
\hline & March & $1 \cdot 01$ & $1 \cdot 79$ & 0.97 & 0.95 & 0.97 & $1 \cdot 64$ \\
\hline Key & & & & & & & \\
\hline
\end{tabular}

\begin{tabular}{|llll}
$\begin{array}{l}\geq 0.95- \\
1.05\end{array}$ & Matched & $\begin{array}{l}>1 \cdot 05- \\
1 \cdot 25\end{array}$ & $\begin{array}{l}\text { Moderately } \\
\text { over- } \\
\text { represented }\end{array}$ \\
\hline $\begin{array}{l}<0.95- \\
0.75\end{array}$ & $\begin{array}{l}\text { Moderately } \\
\text { under- } \\
\text { represented }\end{array}$ & $>1 \cdot 25-1.5$ & $\begin{array}{l}\text { Over- } \\
\text { represented }\end{array}$ \\
\hline $\begin{array}{l}<0.75- \\
0.5\end{array}$ & $\begin{array}{l}\text { Under- } \\
\text { represented }\end{array}$ & $>1 \cdot 5-2$ & $\begin{array}{l}\text { Highly } \\
\text { over- } \\
\text { represented }\end{array}$ \\
\hline$<0.5$ & $\begin{array}{l}\text { Highly } \\
\text { under- } \\
\text { represented }\end{array}$ & $>2$ & $\begin{array}{l}\text { Extremely } \\
\text { over- } \\
\text { represented }\end{array}$ \\
\hline
\end{tabular}

Family Planning service. For the FP service area more data were found in the registers than in the tallysheets (DR less than 1). Comparing earlier years (2014 and 2015) against recent ones (2016 and 2017), a 
high improvement was observed at transmission phase (Table 5). However, under-representation of data in tally-sheets did not improve. Overall, half of the indicators in FP services performed quite well with data presenting good matching between tally-sheets, registers and report-forms. Indicator on cervical cancer screening presented a DR less than 1 for Diff1 indicating more data were recorded in the registers than tally-sheets. The screening for breast cancer had a DR of 1.34 for Diff2 indicating data were compiled in report forms but not indicated in registers. Variation between district performance in FP was observed more in Diff1. 
Table 5

Data accuracy as indicated by difference ratio for the family planning (FP) service area

\begin{tabular}{|c|c|c|c|c|c|c|c|}
\hline \multirow[t]{3}{*}{ Year } & \multirow[t]{3}{*}{ Month } & \multicolumn{2}{|c|}{ Health facility phase } & \multicolumn{3}{|c|}{ Transmission phase } & \multirow{3}{*}{$\begin{array}{l}\text { Robust } \\
\text { Diff } 6 \\
\text { DHIS2 } \\
\text { vs. } \\
\text { Registers }\end{array}$} \\
\hline & & Diff 1 & Diff 2 & Diff 3 & Diff 4 & Diff 5 & \\
\hline & & $\begin{array}{l}\text { Tally vs. } \\
\text { Registers }\end{array}$ & $\begin{array}{l}\text { Report } \\
\text { (Facility) } \\
\text { vs. } \\
\text { Registers }\end{array}$ & $\begin{array}{l}\text { Report } \\
\text { (District) vs. } \\
\text { Report } \\
\text { (Facility) }\end{array}$ & $\begin{array}{l}\text { DHIS2 } \\
\text { vs. } \\
\text { Report } \\
\text { (Facility) }\end{array}$ & $\begin{array}{l}\text { DHIS2 } \\
\text { vs. } \\
\text { Report } \\
\text { (District) }\end{array}$ & \\
\hline \multirow[t]{3}{*}{2014} & Oct & 0.57 & $1 \cdot 14$ & $1 \cdot 06$ & $1 \cdot 11$ & 1.09 & $1 \cdot 33$ \\
\hline & Nov & $0 \cdot 75$ & 0.95 & $1 \cdot 04$ & $1 \cdot 20$ & $1 \cdot 13$ & $1 \cdot 19$ \\
\hline & Dec & $0 \cdot 60$ & $1 \cdot 15$ & $1 \cdot 00$ & $1 \cdot 28$ & $1 \cdot 21$ & 0.99 \\
\hline \multirow[t]{3}{*}{2015} & July & $1 \cdot 18$ & 1.33 & 0.99 & 1.03 & 0.99 & $1 \cdot 37$ \\
\hline & Aug & $1 \cdot 38$ & $1 \cdot 39$ & $1 \cdot 00$ & $1 \cdot 09$ & $1 \cdot 19$ & $1 \cdot 58$ \\
\hline & Sept & $0 \cdot 81$ & $1 \cdot 15$ & 0.95 & 0.98 & 0.98 & $1 \cdot 00$ \\
\hline \multirow[t]{3}{*}{2016} & Apr & $0 \cdot 76$ & $1 \cdot 08$ & 0.94 & 0.93 & 0.97 & $1 \cdot 03$ \\
\hline & May & $0 \cdot 84$ & $1 \cdot 06$ & 0.95 & 0.95 & 0.95 & $1 \cdot 07$ \\
\hline & Jun & $0 \cdot 80$ & 1.09 & 0.95 & 0.94 & $1 \cdot 00$ & $1 \cdot 12$ \\
\hline \multirow[t]{3}{*}{2017} & Jan & $0 \cdot 76$ & 0.93 & 0.94 & 0.98 & $1 \cdot 05$ & $0 \cdot 85$ \\
\hline & Feb & $0 \cdot 67$ & $0 \cdot 79$ & 0.97 & 0.96 & 0.99 & $0 \cdot 80$ \\
\hline & March & 0.83 & $0 \cdot 87$ & 1.00 & 0.98 & 0.96 & 0.93 \\
\hline Key & & & & & & & \\
\hline
\end{tabular}

\begin{tabular}{|llll}
$\begin{array}{l}\geq 0.95- \\
1.05\end{array}$ & Matched & $\begin{array}{l}>1.05- \\
1.25\end{array}$ & $\begin{array}{l}\text { Moderately } \\
\text { over- } \\
\text { represented }\end{array}$ \\
\hline $\begin{array}{l}<0.95- \\
0.75\end{array}$ & $\begin{array}{l}\text { Moderately } \\
\text { under- } \\
\text { represented }\end{array}$ & $>1 \cdot 25-1.5$ & $\begin{array}{l}\text { Over- } \\
\text { represented }\end{array}$ \\
\hline $\begin{array}{l}<0.75- \\
0.5\end{array}$ & $\begin{array}{l}\text { Under- } \\
\text { represented }\end{array}$ & $>1 \cdot 5-2$ & $\begin{array}{l}\text { Highly } \\
\text { over- } \\
\text { represented }\end{array}$ \\
\hline$<0.5$ & $\begin{array}{l}\text { Highly } \\
\text { under- } \\
\text { represented }\end{array}$ & $>2$ & $\begin{array}{l}\text { Extremely } \\
\text { over- } \\
\text { represented }\end{array}$ \\
\hline
\end{tabular}

OPD service. This service area indicated the highest levels of mismatch in the HF and robust phases. Diff1 showed moderate over-representation in tally-sheets versus registers, which improved significantly over time suggesting adoption on the use of tally-sheets. Extremely large Diff2 and Diff6 values were observed 
in 2014-2015. It was observed that records in reports could go up to over 5-7-times higher than register records, but was better in 2017 suggesting an improvement in client registration. Diff2 and Diff6 differed indicating revision of data before been entered in DHIS2 with not documentation (Table 6). OPD indicators did not perform well. Data obtained from registers were much less than in the report forms. The indicator of mild/severe anaemia performed worse with DR value indicating a difference of over 6-times between register records and report form. Blood smear positive records were corrected in report forms with changes documented (Diff3/Diff4 >1.3). The performance varied between districts, with Kinondoni and Kahama having high levels of data over-representation. 
Table 6

Data accuracy as indicated by difference ratio for the outpatient service area

\begin{tabular}{|c|c|c|c|c|c|c|c|}
\hline \multirow[t]{3}{*}{ Year } & \multirow[t]{3}{*}{ Month } & \multicolumn{2}{|c|}{ Health facility phase } & \multicolumn{3}{|c|}{ Transmission phase } & \multirow{3}{*}{$\begin{array}{l}\text { Robust } \\
\text { Diff } 6 \\
\text { DHIS2 } \\
\text { vs. } \\
\text { Registers }\end{array}$} \\
\hline & & Diff 1 & Diff 2 & Diff 3 & Diff 4 & Diff 5 & \\
\hline & & $\begin{array}{l}\text { Tally vs. } \\
\text { Registers }\end{array}$ & $\begin{array}{l}\text { Report } \\
\text { (Facility) } \\
\text { vs. } \\
\text { Registers }\end{array}$ & $\begin{array}{l}\text { Report } \\
\text { (District) vs. } \\
\text { Report } \\
\text { (Facility) }\end{array}$ & $\begin{array}{l}\text { DHIS2 } \\
\text { vs. } \\
\text { Report } \\
\text { (Facility) }\end{array}$ & $\begin{array}{l}\text { DHIS2 } \\
\text { vs. } \\
\text { Report } \\
\text { (District) }\end{array}$ & \\
\hline \multirow[t]{3}{*}{2014} & Oct & $1 \cdot 76$ & 6.94 & $1 \cdot 72$ & $1 \cdot 19$ & $1 \cdot 00$ & $7 \cdot 10$ \\
\hline & Nov & $1 \cdot 71$ & $3 \cdot 33$ & $1 \cdot 58$ & $1 \cdot 34$ & 0.99 & $5 \cdot 55$ \\
\hline & Dec & $1 \cdot 50$ & $7 \cdot 63$ & $1 \cdot 11$ & 0.99 & $0 \cdot 88$ & $6 \cdot 56$ \\
\hline \multirow[t]{3}{*}{2015} & July & $1 \cdot 47$ & 5.35 & 1.05 & 1.01 & 0.99 & $6 \cdot 25$ \\
\hline & Aug & $1 \cdot 04$ & $3 \cdot 70$ & $1 \cdot 03$ & 0.96 & 0.97 & $3 \cdot 43$ \\
\hline & Sept & $1 \cdot 61$ & $2 \cdot 41$ & $1 \cdot 11$ & $0 \cdot 88$ & $0 \cdot 86$ & $3 \cdot 44$ \\
\hline \multirow[t]{3}{*}{2016} & Apr & $1 \cdot 07$ & $2 \cdot 87$ & $1 \cdot 13$ & $1 \cdot 12$ & $1 \cdot 07$ & $3 \cdot 19$ \\
\hline & May & 1.57 & $4 \cdot 23$ & 0.95 & 1.00 & 1.02 & $4 \cdot 82$ \\
\hline & Jun & $0 \cdot 74$ & $5 \cdot 66$ & $1 \cdot 06$ & 0.90 & $1 \cdot 32$ & $4 \cdot 66$ \\
\hline \multirow[t]{3}{*}{2017} & Jan & $1 \cdot 06$ & $2 \cdot 92$ & 0.95 & $1 \cdot 18$ & $1 \cdot 13$ & $3 \cdot 60$ \\
\hline & Feb & $1 \cdot 31$ & $2 \cdot 10$ & 0.95 & 0.93 & 0.92 & 3.05 \\
\hline & March & $1 \cdot 24$ & $2 \cdot 27$ & 1.02 & $1 \cdot 10$ & 0.94 & $3 \cdot 26$ \\
\hline \multicolumn{8}{|l|}{ Key } \\
\hline $\begin{array}{l}\geq 0.95- \\
1.05\end{array}$ & Matched & $\begin{array}{l}>1 \cdot 05- \\
1 \cdot 25\end{array}$ & $\begin{array}{l}\text { Moderately } \\
\text { over- } \\
\text { represented }\end{array}$ & & & & \\
\hline $\begin{array}{l}<0.95- \\
0.75\end{array}$ & $\begin{array}{l}\text { Moderately } \\
\text { under- } \\
\text { represented }\end{array}$ & $>1 \cdot 25-1 \cdot 5$ & $\begin{array}{l}\text { Over- } \\
\text { represented }\end{array}$ & & & & \\
\hline $\begin{array}{l}<0.75- \\
0.5\end{array}$ & $\begin{array}{l}\text { Under- } \\
\text { represented }\end{array}$ & $>1 \cdot 5-2$ & $\begin{array}{l}\text { Highly } \\
\text { over- } \\
\text { represented }\end{array}$ & & & & \\
\hline$<0.5$ & $\begin{array}{l}\text { Highly } \\
\text { under- } \\
\text { represented }\end{array}$ & $>2$ & $\begin{array}{l}\text { Extremely } \\
\text { over- } \\
\text { represented }\end{array}$ & & & & \\
\hline
\end{tabular}

Inpatient service. IPD was among the service areas that indicated a high level of mismatch, more particularly over-representation of data. This was clearly presented at the HF phase (report at HF versus register counts). For Diff1, an extreme over-representation was observed in 2014, though it improved 
during 2017 related to the use of tally-sheets. For Diff2 there was no indication of improvement observed during the 4-year period under review (Table 7). At transmission phase, an improvement was observed as the data matched better for the 2016 and 2017. Most of IPD indicators presented difference between data sources of at least over $50 \%$. Data on severe anaemia was extremely over-represented in tally-sheets and report forms compared to register records (Diff1 $=2.38$ and Diff2 $=3.81$ ). This implies that data were not found in registers but were marked in tally-sheets and recorded in the report forms. High difference between registers and reports were observed. There was high variation between district performance in IPD data accuracy mainly in Diff1 and Diff2 with Kinondoni and Dodoma under-utilizing tally-sheets and Mbulu over-representing data in the reports. 
Table 7

Data accuracy as indicated by difference ratio for the Inpatient service area

\begin{tabular}{|c|c|c|c|c|c|c|c|}
\hline \multirow[t]{3}{*}{ Year } & \multirow[t]{3}{*}{ Month } & \multicolumn{2}{|c|}{ Health facility phase } & \multicolumn{3}{|c|}{ Transmission phase } & \multirow{3}{*}{$\begin{array}{l}\text { Robust } \\
\text { Diff } 6 \\
\text { DHIS2 } \\
\text { vs. } \\
\text { Registers }\end{array}$} \\
\hline & & Diff 1 & Diff 2 & Diff 3 & Diff 4 & Diff 5 & \\
\hline & & $\begin{array}{l}\text { Tally vs. } \\
\text { Registers }\end{array}$ & $\begin{array}{l}\text { Report } \\
\text { (Facility) } \\
\text { vs. } \\
\text { Registers }\end{array}$ & $\begin{array}{l}\text { Report } \\
\text { (District) vs. } \\
\text { Report } \\
\text { (Facility) }\end{array}$ & $\begin{array}{l}\text { DHIS2 } \\
\text { vs. } \\
\text { Report } \\
\text { (Facility) }\end{array}$ & $\begin{array}{l}\text { DHIS2 } \\
\text { vs. } \\
\text { Report } \\
\text { (District) }\end{array}$ & \\
\hline \multirow[t]{3}{*}{2014} & Oct & $1 \cdot 31$ & $2 \cdot 84$ & $1 \cdot 53$ & $1 \cdot 23$ & 0.94 & $3 \cdot 20$ \\
\hline & Nov & $2 \cdot 11$ & $3 \cdot 67$ & $1 \cdot 29$ & 0.97 & 0.91 & $4 \cdot 07$ \\
\hline & Dec & $2 \cdot 28$ & $2 \cdot 45$ & $1 \cdot 61$ & $1 \cdot 79$ & $1 \cdot 05$ & $2 \cdot 58$ \\
\hline \multirow[t]{3}{*}{2015} & July & 1.07 & $2 \cdot 73$ & $1 \cdot 47$ & $1 \cdot 28$ & 0.93 & $2 \cdot 42$ \\
\hline & Aug & $1 \cdot 29$ & $3 \cdot 00$ & $1 \cdot 82$ & $1 \cdot 59$ & $1 \cdot 04$ & $3 \cdot 13$ \\
\hline & Sept & $1 \cdot 35$ & $2 \cdot 98$ & $1 \cdot 01$ & $1 \cdot 03$ & $2 \cdot 16$ & $2 \cdot 22$ \\
\hline \multirow[t]{3}{*}{2016} & Apr & $2 \cdot 50$ & $2 \cdot 84$ & $1 \cdot 14$ & $1 \cdot 02$ & 0.99 & $2 \cdot 68$ \\
\hline & May & $1 \cdot 89$ & 2.89 & $1 \cdot 12$ & 0.92 & 0.91 & $2 \cdot 22$ \\
\hline & Jun & $2 \cdot 33$ & $2 \cdot 78$ & $1 \cdot 17$ & $1 \cdot 16$ & 0.93 & $3 \cdot 48$ \\
\hline \multirow[t]{3}{*}{2017} & Jan & $1 \cdot 70$ & $2 \cdot 50$ & $1 \cdot 44$ & $1 \cdot 39$ & $1 \cdot 02$ & $3 \cdot 47$ \\
\hline & Feb & $1 \cdot 15$ & $2 \cdot 86$ & 1.03 & 0.91 & 0.95 & $2 \cdot 64$ \\
\hline & March & $1 \cdot 24$ & $2 \cdot 66$ & 0.97 & 0.91 & 0.95 & $2 \cdot 62$ \\
\hline \multicolumn{8}{|l|}{ Key } \\
\hline $\begin{array}{l}\geq 0.95- \\
1.05\end{array}$ & Matched & $\begin{array}{l}>1 \cdot 05- \\
1 \cdot 25\end{array}$ & $\begin{array}{l}\text { Moderately } \\
\text { over- } \\
\text { represented }\end{array}$ & & & & \\
\hline $\begin{array}{l}<0.95- \\
0.75\end{array}$ & $\begin{array}{l}\text { Moderately } \\
\text { under- } \\
\text { represented }\end{array}$ & $>1 \cdot 25-1 \cdot 5$ & $\begin{array}{l}\text { Over- } \\
\text { represented }\end{array}$ & & & & \\
\hline $\begin{array}{l}<0.75- \\
0.5\end{array}$ & $\begin{array}{l}\text { Under- } \\
\text { represented }\end{array}$ & $>1 \cdot 5-2$ & $\begin{array}{l}\text { Highly } \\
\text { over- } \\
\text { represented }\end{array}$ & & & & \\
\hline$<0.5$ & $\begin{array}{l}\text { Highly } \\
\text { under- } \\
\text { represented }\end{array}$ & $>2$ & $\begin{array}{l}\text { Extremely } \\
\text { over- } \\
\text { represented }\end{array}$ & & & & \\
\hline
\end{tabular}

PITC service. In this service-area, Diff2 went from moderate (in 2014) to extremes (in 2017) indicating weakness in registration process. PITC reports were highly manipulated during transmission phase before data was entered in DHIS2, marked by difference between Diff2 and Diff6 and large Diff3/Diff4 (Table 8). 
Little improvements were observed over the years. Indicator on 'number of new clients' was 2-fold overrepresented between register counts and reported records and its data was corrected before been entered in DHIS2. Kinondoni, Kibaha and Nkasi showed high levels of data over-representation. Mbulu had matched data for Diff2 but high Diff6 indicating the submitted reports were revised before data entered in the DHIS2 and the changes were not documented. Nkasi had the highest Diff4 and Diff5 indicating corrections made during the transmission phase. 
Table 8

Data accuracy as indicated by difference ratio for the PITC service area

\begin{tabular}{|c|c|c|c|c|c|c|}
\hline \multirow[t]{3}{*}{ Year } & \multirow[t]{3}{*}{ Month } & \multirow{3}{*}{$\begin{array}{l}\text { Health } \\
\text { facility } \\
\text { phase }\end{array}$} & \multicolumn{3}{|c|}{ Transmission phase } & \multirow{3}{*}{$\begin{array}{l}\text { Robust } \\
\\
\text { Diff } 6 \\
\text { DHIS2 vs. } \\
\text { Registers }\end{array}$} \\
\hline & & & Diff 3 & Diff 4 & Diff 5 & \\
\hline & & & $\begin{array}{l}\text { Report (District) } \\
\text { vs. Report } \\
\text { (Facility) }\end{array}$ & $\begin{array}{l}\text { DHIS2 vs. } \\
\text { Report } \\
\text { (Facility) }\end{array}$ & $\begin{array}{l}\text { DHIS2 vs. } \\
\text { Report } \\
\text { (District) }\end{array}$ & \\
\hline \multirow[t]{3}{*}{2014} & Oct & 2.39 & 0.88 & 1.11 & 0.76 & 2.21 \\
\hline & Nov & 1.09 & 1.00 & 1.76 & 0.99 & 1.99 \\
\hline & Dec & 1.39 & 1.01 & 0.89 & 0.93 & 2.16 \\
\hline \multirow[t]{3}{*}{2015} & July & 1.82 & 1.00 & 0.94 & 0.91 & 2.07 \\
\hline & Aug & 1.59 & 0.90 & 1.44 & 1.10 & 2.39 \\
\hline & Sept & 1.92 & 0.85 & 1.58 & 1.14 & 2.95 \\
\hline \multirow[t]{3}{*}{2016} & Apr & 1.56 & 1.47 & 1.45 & 0.90 & 3.52 \\
\hline & May & 1.76 & 1.57 & 1.56 & 1.08 & 3.04 \\
\hline & Jun & 2.84 & 1.09 & 0.98 & 0.96 & 2.51 \\
\hline \multirow[t]{3}{*}{2017} & Jan & 1.80 & 1.38 & 1.07 & 1.11 & 2.26 \\
\hline & Feb & 2.11 & 1.15 & 1.02 & 1.06 & 2.20 \\
\hline & March & 1.48 & 1.01 & 1.30 & 1.56 & 1.69 \\
\hline Key & & & & & & \\
\hline
\end{tabular}

\begin{tabular}{|llll}
$\begin{array}{l}\geq 0.95- \\
1.05\end{array}$ & Matched & $>1.05-1.25$ & $\begin{array}{l}\text { Moderately } \\
\text { over- } \\
\text { represented }\end{array}$ \\
\hline $\begin{array}{l}<0.95- \\
0.75\end{array}$ & $\begin{array}{l}\text { Moderately } \\
\text { under- } \\
\text { represented }\end{array}$ & $>1.25-1.5$ & $\begin{array}{l}\text { Over- } \\
\text { represented }\end{array}$ \\
\hline$<0.75-$ & $\begin{array}{l}\text { Under- } \\
\text { represented }\end{array}$ & $>1.5-2$ & $\begin{array}{l}\text { Highly over- } \\
\text { represented }\end{array}$ \\
\hline$<0.5$ & $\begin{array}{l}\text { Highly } \\
\text { under- } \\
\text { represented }\end{array}$ & $>2$ & $\begin{array}{l}\text { Extremely over- } \\
\text { represented }\end{array}$ \\
\hline
\end{tabular}

An overall annual pattern indicated slight improvement on Diff1 (from 1.37 in 2014 to 1.26 in 2017), but a high improvement on Diff2 (from 2.61 in 2014 to 1.70 in 2017). This indicates that even though tallysheets were not fully utilized, the reports were better prepared when comparing 2014 and 2017 statuses. 
Similarly, there was a marked improvement in values for Diff6 from 2.72 in 2014 to 1.76 in 2017, indicating less variation between register' records and DHIS2 entries over the years. Data accuracy by HF levels categorized by service areas indicates high Diff2 and Diff6 for hospitals, and in OPD, IPD, ANC, and PNC (Table 9). Data accuracy was observed to vary between HFs even within districts. 
Table 9

Data accuracy as indicated by difference ratio by HF levels and service area

\begin{tabular}{|c|c|c|c|c|c|c|c|}
\hline \multirow{3}{*}{$\begin{array}{l}\text { Service } \\
\text { area }\end{array}$} & \multirow{3}{*}{$\begin{array}{l}\text { Facility } \\
\text { level }\end{array}$} & \multicolumn{2}{|c|}{ Health facility phase } & \multicolumn{3}{|c|}{ Transmission phase } & \multirow{3}{*}{$\begin{array}{l}\begin{array}{l}\text { Robust } \\
\text { phase }\end{array} \\
\text { Diff } 6 \\
\text { DHIS2 } \\
\text { vs. } \\
\text { Registers }\end{array}$} \\
\hline & & Diff 1 & Diff 2 & Diff 3 & Diff 4 & Diff 5 & \\
\hline & & $\begin{array}{l}\text { Tally vs. } \\
\text { Registers }\end{array}$ & $\begin{array}{l}\text { Report } \\
\text { (Facility) } \\
\text { vs. } \\
\text { Registers }\end{array}$ & $\begin{array}{l}\text { Report } \\
\text { (District) } \\
\text { vs. Report } \\
\text { (Facility) }\end{array}$ & $\begin{array}{l}\text { DHIS2 } \\
\text { vs. } \\
\text { Report } \\
\text { (Facility) }\end{array}$ & $\begin{array}{l}\text { DHIS2 } \\
\text { vs. } \\
\text { Report } \\
\text { (District) }\end{array}$ & \\
\hline \multirow[t]{3}{*}{ ANC } & Dispensary & $1 \cdot 28$ & $1 \cdot 53$ & $1 \cdot 02$ & $1 \cdot 01$ & $1 \cdot 00$ & $1 \cdot 31$ \\
\hline & $\begin{array}{l}\text { Health } \\
\text { Centre }\end{array}$ & $1 \cdot 64$ & $2 \cdot 25$ & $1 \cdot 03$ & $1 \cdot 06$ & $1 \cdot 06$ & $1 \cdot 92$ \\
\hline & Hospital & $2 \cdot 51$ & 3.93 & 1.05 & $1 \cdot 15$ & $1 \cdot 07$ & $3 \cdot 71$ \\
\hline \multirow[t]{3}{*}{ FP } & Dispensary & $0 \cdot 75$ & 0.97 & 0.98 & $1 \cdot 05$ & $1 \cdot 05$ & 0.97 \\
\hline & $\begin{array}{l}\text { Health } \\
\text { Centre }\end{array}$ & 0.92 & $1 \cdot 03$ & 0.98 & 0.99 & $1 \cdot 04$ & $1 \cdot 10$ \\
\hline & Hospital & $1 \cdot 06$ & $1 \cdot 63$ & 0.98 & $1 \cdot 03$ & $1 \cdot 01$ & $1 \cdot 65$ \\
\hline \multirow[t]{3}{*}{ IPD } & Dispensary & $0 \cdot 50$ & $1 \cdot 60$ & $1 \cdot 00$ & 0.67 & $0 \cdot 70$ & $0 \cdot 40$ \\
\hline & $\begin{array}{l}\text { Health } \\
\text { Centre }\end{array}$ & $1 \cdot 53$ & $1 \cdot 76$ & 1.03 & $0 \cdot 89$ & 0.94 & $1 \cdot 48$ \\
\hline & Hospital & $1 \cdot 95$ & $4 \cdot 25$ & $1 \cdot 66$ & $1 \cdot 61$ & $1 \cdot 26$ & $4 \cdot 76$ \\
\hline \multirow[t]{3}{*}{ LnD } & Dispensary & 1.06 & $1 \cdot 15$ & $1 \cdot 10$ & 1.04 & 1.04 & $1 \cdot 19$ \\
\hline & $\begin{array}{l}\text { Health } \\
\text { Centre }\end{array}$ & $1 \cdot 49$ & $1 \cdot 56$ & $1 \cdot 08$ & $1 \cdot 01$ & 0.99 & $1 \cdot 53$ \\
\hline & Hospital & $1 \cdot 31$ & $1 \cdot 84$ & $2 \cdot 00$ & $1 \cdot 87$ & $1 \cdot 03$ & $1 \cdot 79$ \\
\hline \multirow[t]{3}{*}{ OPD } & Dispensary & $1 \cdot 26$ & $2 \cdot 67$ & $1 \cdot 16$ & $1 \cdot 07$ & $1 \cdot 02$ & $2 \cdot 42$ \\
\hline & $\begin{array}{l}\text { Health } \\
\text { Centre }\end{array}$ & $1 \cdot 38$ & $3 \cdot 48$ & $1 \cdot 04$ & 0.97 & $1 \cdot 01$ & $4 \cdot 37$ \\
\hline & Hospital & $1 \cdot 37$ & $9 \cdot 08$ & $1 \cdot 06$ & $1 \cdot 05$ & 0.97 & $12 \cdot 27$ \\
\hline \multirow[t]{3}{*}{ PITC } & Dispensary & & $1 \cdot 36$ & $1 \cdot 37$ & $1 \cdot 29$ & 0.97 & $1 \cdot 83$ \\
\hline & $\begin{array}{l}\text { Health } \\
\text { Centre }\end{array}$ & & $2 \cdot 35$ & $1 \cdot 13$ & $1 \cdot 08$ & $1 \cdot 02$ & $3 \cdot 20$ \\
\hline & Hospital & & 1.95 & 0.96 & $1 \cdot 59$ & $1 \cdot 53$ & $2 \cdot 43$ \\
\hline \multirow[t]{2}{*}{ PNC } & Dispensary & $1 \cdot 01$ & $1 \cdot 18$ & 0.98 & 0.96 & 0.99 & $1 \cdot 10$ \\
\hline & $\begin{array}{l}\text { Health } \\
\text { Centre }\end{array}$ & $1 \cdot 26$ & $1 \cdot 59$ & 0.98 & $1 \cdot 07$ & $1 \cdot 00$ & $1 \cdot 70$ \\
\hline
\end{tabular}




\begin{tabular}{|c|c|c|c|}
\hline & Hospital & $1 \cdot 67$ & $4 \cdot 11$ \\
\hline \multirow{3}{*}{$\begin{array}{l}\text { All } \\
\text { Services }\end{array}$} & Dispensary & $1 \cdot 11$ & $1 \cdot 49$ \\
\hline & $\begin{array}{l}\text { Health } \\
\text { Centre }\end{array}$ & $1 \cdot 42$ & $2 \cdot 07$ \\
\hline & Hospital & $1 \cdot 73$ & 3.94 \\
\hline \multicolumn{4}{|l|}{ Key } \\
\hline $\begin{array}{l}\geq 0.95- \\
1.05\end{array}$ & Matched & $\begin{array}{l}>1 \cdot 05- \\
1 \cdot 25\end{array}$ & $\begin{array}{l}\text { Moderately } \\
\text { over- } \\
\text { represented }\end{array}$ \\
\hline $\begin{array}{l}<0.95- \\
0.75\end{array}$ & $\begin{array}{l}\text { Moderately } \\
\text { under- } \\
\text { represented }\end{array}$ & $>1 \cdot 25-1 \cdot 5$ & $\begin{array}{l}\text { Over- } \\
\text { represented }\end{array}$ \\
\hline $\begin{array}{l}<0.75- \\
0.5\end{array}$ & $\begin{array}{l}\text { Under- } \\
\text { represented }\end{array}$ & $>1 \cdot 5-2$ & $\begin{array}{l}\text { Highly } \\
\text { over- } \\
\text { represented }\end{array}$ \\
\hline$<0.5$ & $\begin{array}{l}\text { Highly } \\
\text { under- } \\
\text { represented }\end{array}$ & $>2$ & $\begin{array}{l}\text { Extremely } \\
\text { over- } \\
\text { represented }\end{array}$ \\
\hline
\end{tabular}

\section{Discussion}

Registers and report forms were the most commonly available and used HMIS tools in healthcare facilities in Tanzania with high variation between levels of the health system. The urban districts indicated low utilization than rural ones; lower-level HFs and faith-based owned facilities performed better than higher level and government facilities. The service areas under reproductive and child health performed better than other service areas. The availability rates of report forms submitted to districts indicate weakness in transmission or storage of reports at the district level. Data accuracy varied by district, facility characteristics, service area and indicators. The volume of data and complexity in the process of getting indicator data affected the accuracy significantly. Both tool utilisation and data accuracy improved from 2014 to 2017 . We observed reduction in variation on performance within the health system level over time. This is likely to imply improvement and homogeneity in the functioning, resulting on equality on resource allocation and capacity strengthening programmes. Our methodology assessed the quality while paying attention to health system levels and processes behind data generation to allow systematic thinking along the concerns identified.

Variations and inadequate utilization of HMIS tools by facility characteristics have been reported previously in Tanzania and elsewhere [11, 21, 24]. Private-owned facilities, hospitals and healthcare facilities with high client volume are known to significantly affect the quality of HMIS data due to poor adherence in recording procedures, incompleteness and late reporting $[3,5,6,9,13,25-27]$. The performance of urban districts on HMIS utilization and data quality has been reported by other studies 
with inconclusive results $[12,15,26]$. Healthcare facilities in urban areas are assumed to have infrastructure, sufficient workforce, frequent supervision hence expected to perform better. However, these settings have high workload due to large population and targeted by multiple programmes, frequent change of human resource, and serving many facilities resulting in insufficient supervision despite proximity to district offices. These factors are frequently ignored though do highly compromise data quality [2].

There was a high level of mismatch between the register records and those in tally-sheets or report forms, which were highly over-represented. This was common in service areas and healthcare facilities receiving relatively larger number of clients [26]. These findings highlight difficulties in the utilization of registers when many clients need to be simultaneously attended by the same healthcare provider. Due to the overburden, inadequate staffing, and the fact that recording is paper-based, it could seem practical and sufficient to tally records in pre-populated sheets than to write patient details in registers, not adherence to recording procedures/guidelines but be able to make a report $[11,12]$. This phenomenon could explain a significant variation on quality observed between indicators when register counts were compared to subsequent sources $[11,12]$. Indicators dealing with a large amount of data and direct client contact, and those associated with dispensing medication/vaccination performed worse [24]. Complex indicators which include a subset of the population served (ANC-5c), time or day specification (PNC-1a and 2), categorization of disease severity had substantial quality issues.

Over-reported routine HMIS data is a challenge in many countries in SSA $[24,28]$. Our results indicate a clear reduction in the variation of the mismatch, especially for OPD and IPD service areas from 2014 to 2017. However, a high difference between DHIS2 data and registers' records still existed particularly for hospital data. The robust phase presented large DR values for many HFs, implying transmitted data are not of good quality. Since the error originates from the primary source it is difficult to correct it at later stages. A number of studies have reported similar findings in other countries $[11,12,24,26]$. Our methodology detects that HF reports were manipulated before entering DHIS2. However, most often the changes were not documented. Some studies attribute report manipulation with pressure received from superiors to hide poor service provision, enhance the image of facilities, meet targets or justify the use of medicine [11, 24]. Moreover, it could also be due to inadequacy in supervision and data audits $[5,25]$. The variation in data and report management practises within districts, healthcare facilities, and disease programmes has also been documented in other countries $[8,11,24,26]$.

The poor quality of the HMIS data and underperformance found in this study and other studies in SSA is likely to be attributed to the combination of multiple factors. These include insufficient staff with core competence on data management, low motivation and lack of incentives, poor infrastructure, inadequate resources to conduct comprehensive supportive supervision and, lack of standard operating procedures [3, $6,27,29$ ]. Similar challenges were reported in an assessment carried out in 2015/2016 in Tanzania [22]. In Tanzania, the majority of the HMIS focal persons and those dealing with data at facility and district levels are the same healthcare providers, as a result, they are overburdened, thus key operational problems are not readily identified and remedied on a routine basis $[11,26]$. For many years, the HMIS in low-income 
countries have remained paper-based, which is cumbersome, and of uncertain reliability [10]. The DHIS2 has been recently introduced as a tool to aggregate and process routine facility-based data expected to facilitate availability, standardization, quality, timely usage, and evidence-based decisions at different levels of the health system [2, 24]. However, DHIS2 is not the magic bullet and does not solve underlying quality problems currently facing HMIS [24,30]. Quality assurance and audit should be emphasized at each stage of the data journey to detect and fix process-loopholes that compromise quality.

\section{Conclusions}

In conclusion, despite some progress in recent years, the routine HMIS in Tanzania is still weak. Moreover, the DHIS2 at the district level inaccurately reflects what exists at the primary facility levels (data source). These challenges make HMIS an ineffective tool for monitoring health service performance and as a source of data for planning and decision-making. Findings from this study emphasize the importance of data quality auditing exercises to carefully consider the underlying data management processes, indicator types and human resource challenges in drawing conclusions but most important in providing recommendations on improvement of the data quality issues.

\section{Abbreviations}

ANC: Antenatal Care; DHIS2:District Health Information System-2; DR:Difference Ratio; FP:Family Planning; HF:Health facility; HMIS:Health Management Information System; IPD:Inpatient Department; IQR:Interquartile Range; LnD:Labour and Delivery; OPD:Outpatient Department; PITC:Provider Initiated Testing and Counselling.

\section{Declarations}

\section{Ethics approval and consent to participate}

This study received ethical approval from the Medical Research Coordinating Committee of the National Institute for Medical Research Ref. No. NIMR/HQ/R.8a/Vol. IX/2230. Permissions to access hospital registers and reporting documents were sought from the Ministry of Health, Community Development, Gender, Elderly and Children and the respective Regional Administrative Secretaries and Hospital Authorities. No identifiable variables such as names of individuals were collected for this work. Names of health facilities involved in the study were not used for reporting.

\section{Availability of data and material}

The data used are available upon request.

\section{Competing interest}


The authors declare that they have no competing interests

\section{Key}

PITC = Provider-Initiated Testing and Counselling

\section{Fundings}

This study received financial assistance from the Global Fund for AIDS, Malaria and Tuberculosis through the Tanzania Ministry of Health, Community Development, Gender, Elderly and Children.

\section{Authors' contributions}

LEGM, SFR, CJ conceived the original idea and planned the study. SFR contributed to the design, implementation of the research, did the analysis with contributions from LEGM. SFR, EPL, IRM, PKT, DM helped supervised the project. All authors participated in data collection. LEGM wrote the first version of the manuscript. All authors proofread and approved the final version of the manuscript.

\section{Acknowledgements}

We thank the management of the districts and HFs who participated in the study. We are grateful to our research assistants: John Ng'imba, Joyce Kaswamila, Simon Alfred, Jesca Kivinge, Leilath Mtui, Jesca Massawe, Gilbert Mwageni, Glory Lema, Nicholas Lubange, Estaban Mremi, Osyth Sylivester, Neema Lauwo and Isolide Massawe for enthusiasm and dedication. Prof. Daudi Simba and Dr. Calvin Sindato are thanked for their comments in the early version of this manuscript.

\section{Consent to publication}

Not applicable

\section{References}

1. AbouZahr C, Boerma T. Health information systems: the foundations of public health. Bull World Health Organ. 2005 Aug;83(8):578-83.

2. Aiga $H$, Kuroiwa $C$, Takizawa I, Yamagata R. The reality of health information systems: challenges for standardization. Biosci Trends. 2008 Feb;2(1):5-9.

3. Glèlè Ahanhanzo Y, Ouendo E-M, Kpozèhouen A, Levêque A, Makoutodé M, Dramaix-Wilmet M. Data quality assessment in the routine health information system: an application of the Lot Quality Assurance Sampling in Benin. Health Policy Plan. 2015 Sep 1;30(7):837-43. 
4. Chan M, Kazatchkine M, Lob-Levyt J, Obaid T, Schweizer J, Sidibe M, Veneman A, Yamada T. Meeting the demand for results and accountability: a call for action on health data from eight global health agencies. PLoS Med. 2010 Jan;26(1):e1000223. 7(.

5. Franco L, Fields R, Mmbuji PKL, Posner S, Mboera LEG, Jimmerson A, Senkoro KP, Rumisha SF, Shayo EH, Mwami JA. Situation Analysis of Infectious Disease Surveillance in two Districts in Tanzania, 2002. Bethesda, MD; 2003.

6. Mavimbe JC, Braa J, Bjune G. Assessing immunization data quality from routine reports in Mozambique. BMC Public Health. 2005 Dec 11;5(1):108.

7. Kimaro H, Sahay S. An institutional perspective on the process of decentralization of Health Information Systems: a case study from Tanzania. Inf Technol Dev. 2007;13:363-90.

8. Sychareun V, Hansana V, Phengsavanh A, Chaleunvong K, Eunyoung K, Durham J. Data verification at health centers and district health offices in Xiengkhouang and Houaphanh Provinces, Lao PDR. BMC Health Serv Res. 2014 Jun 14;14(1).

9. Mremi IR, Rumisha SF, Chiduo MG, Mangu CD, Mkwashapi DM, Kishamawe C, Lyimo EP, Massawe IS, Matemba LE, Bwana VM, Mboera LEG. Hospital mortality statistics in Tanzania: Availability, accessibility, and quality 2006-2015. Popul Health Metr. 2018 Nov;20(1):16. 16(.

10. Mutale W, Chintu N, Amoroso C, Awoonor-Williams K, Phillips J, Baynes C, Michel C, Taylor A, Sherr K. Improving health information systems for decision making across five sub-Saharan African countries: Implementation strategies from the African Health Initiative. BMC Health Serv Res. 2013;13(Suppl 2):9. Suppl 2(.

11. Amoakoh-Coleman M, Kayode GA, Brown-Davies C, Agyepong IA, Grobbee DE, Klipstein-Grobusch K, Ansah EK. Completeness and accuracy of data transfer of routine maternal health services data in the greater Accra region. BMC Res Notes. 2015;8(1).

12. Gimbel S, Micek M, Lambdin B, Lara J, Karagianis M, Cuembelo F, Gloyd SS, Pfeiffer J, Sherr K. An assessment of routine primary care health information system data quality in Sofala Province, Mozambique. Popul Health Metr. 2011 Dec;13(1):12. 9(.

13. Teklegiorgis K, Tadesse K, Mirutse G, Terefe W. Level of data quality from Health Management Information Systems in a resources limited setting and its associated factors, eastern Ethiopia. SA J Inf Manag. 2016 Aug 10;17(1).

14. Xiao Y, Bochner AF, Makunike B, Holec M, Xaba S, Tshimanga M, Chitimbire V, Barnhart S, Feldacker C. Challenges in data quality: the influence of data quality assessments on data availability and completeness in a voluntary medical male circumcision programme in Zimbabwe. BMJ Open. 2017;7(1):e013562.

15. O’Hagan R, Marx MA, Finnegan KE, Naphini P, Ng'ambi K, Laija K, Wilson E, Park L, Wachepa S, Smith J, Gombwa L, Misomali A, Mleme T, Yosefe S. National Assessment of Data Quality and Associated Systems-Level Factors in Malawi. Glob Heal Sci Pract. 2017 Sep;27(3):367-81. 5(.

16. Chen H, Hailey D, Wang N, Yu P. A review of data quality assessment methods for public health information systems. Int J Environ Res Public Health. 2014 May;14(5):5170-207. 11(. 
17. Rumisha SF, Mboera LEG, Senkoro KP, Gueye D, Mmbuji PK. Monitoring and evaluation of integrated disease surveillance and response in selected districts in Tanzania. Tanzan Health Res Bull. 2007 Jan;9(1):1-11.

18. Mboera LEG, Rumisha SF, Mwanemile EJ, Mziwanda E, Mmbuji PK. Enhancing disease surveillance reporting using public transport in Dodoma District, Central Tanzania. Vol. 7, Tanzania Health Research Bulletin. 2005.

19. Kajeguka AC, Mboera LEG. Information and communication technology: options for strengthening integrated disease surveillance and response at district level in Tanzania. Tanzan Health Res Bull. 2003;5:61-7.

20. Mboera L, Rumisha S, Magesa S, Kitua A. Utilisation of health management information system in disease surveillance in Tanzania. Tanzan J Health Res. 2001;3(2):15-7.

21. Simba DO, Mwangu MA. Quality of a routine data collection system for health : case of Kinondoni district in the Dar es Salaam region, Tanzania. South African J Inf Manag. 2005;7(2).

22. URT. Independent Verification of Health Service Results Supported by the Health Basket Fund and the Strengthening of Primary Health Care for Results Programme for financial year 2015/16. 2016.

23. Tanzania Demographic and Health Survey and Malaria Indicator Survey. Dar es Salaam, Tanzania and Rockville, Maryland, USA; 2016.

24. Bhattacharya AA, Umar N, Audu A, Felix H, Allen E, Schellenberg JRM, Marchant T. Quality of routine facility data for monitoring priority maternal and newborn indicators in DHIS2: A case study from Gombe State, Nigeria. PLoS ONE 14(1): e0211265.

25. Kihuba E, Gathara D, Mwinga S, Mulaku M, Kosgei R, Mogoa W, Nyamai R, Englilsh M. Assessing the ability of health information systems in hospitals to support evidence-informed decisions in Kenya. Glob Health Action. 2014;7(1).

26. Kasambara A, Kumwenda S, Kalulu K, Lungu K, Beattie T, Masangwi S, Ferguson N, Morse T. Assessment of implementation of the health management information system at the district level in southern Malawi. Malawi Med J. 2017;29(3):240.

27. Adeya G, Bigirimana A, Cavanaugh K, Franco L. Rapid assessment of the health system in Benin: April 2006. Submitted to the US Agency for International Development. 2007.

28. Endriyas M, Alano A, Mekonnen E, Ayele S, Kelaye T, Shiferaw M, Misganaw T, Samuel T, Hailemariam T, Hailu S. Understanding performance data: Health management information system data accuracy in Southern Nations Nationalities and People's Region, Ethiopia. BMC Health Serv Res. 2019 Mar 18;19(1):175.

29. Yazdi-Feyzabadi V, Emami M, Mehrolhassani MH. Health information system in primary health care: the challenges and barriers from local providers' perspective of an area in Iran. Int J Prev Med. 2015;6.

30. Maokola W, Willey BA, Shirima K, Chemba M, Armstrong Schellenberg JRM, Mshinda H, Alonso P, Tanner M, Schellenberg D. Enhancing the routine health information system in rural southern Tanzania: Successes, challenges and lessons learned. Trop Med Int Heal. 2011 Jun;16(6):721-30. 
Figures

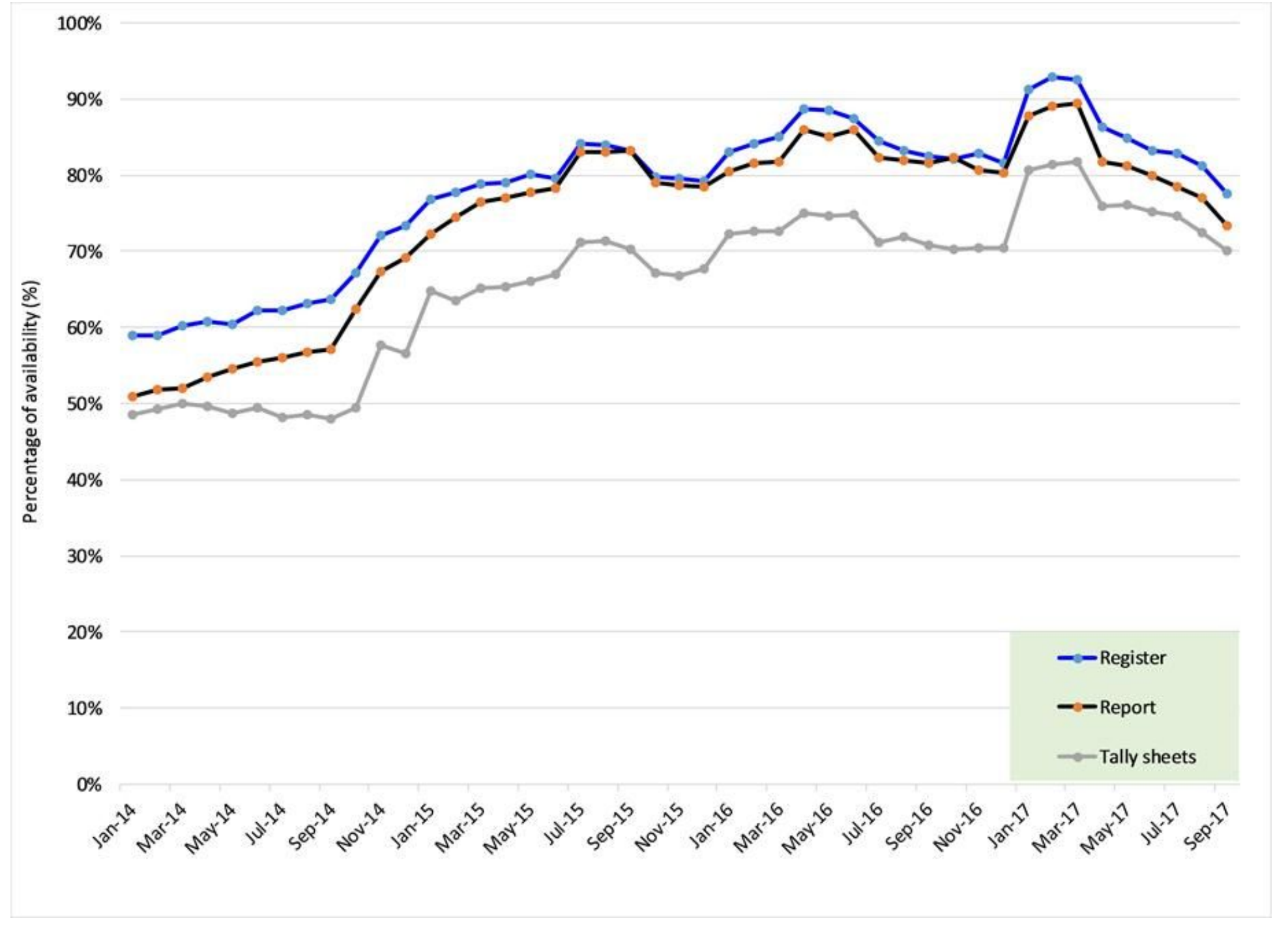

Figure 1

Overall trend of availability rate of HMIS tools by type 


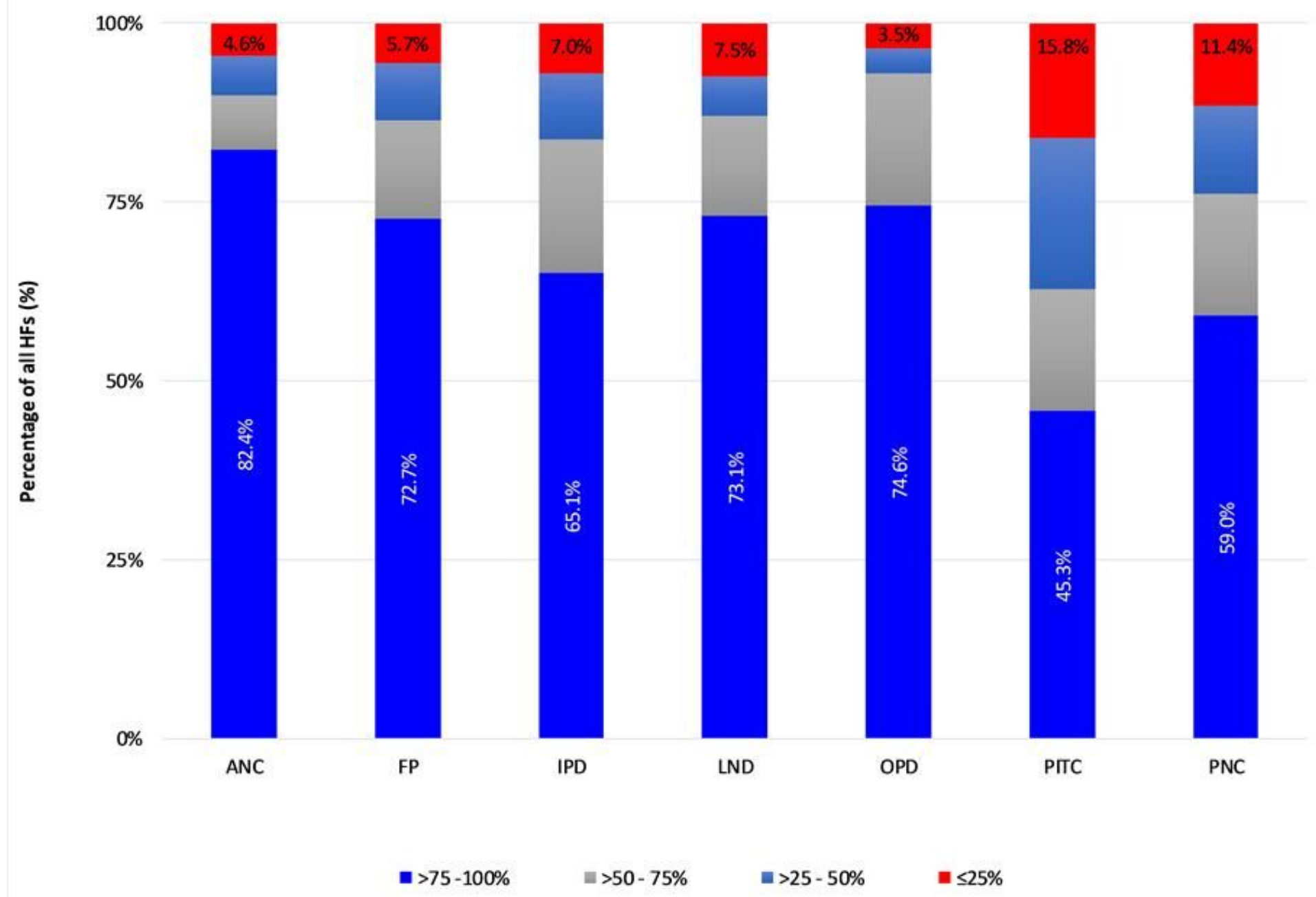

Figure 2

Register availability rates by service area categorized into very high, high, average, and low windows. The percentages were calculated conditioning on the facilities providing the service 


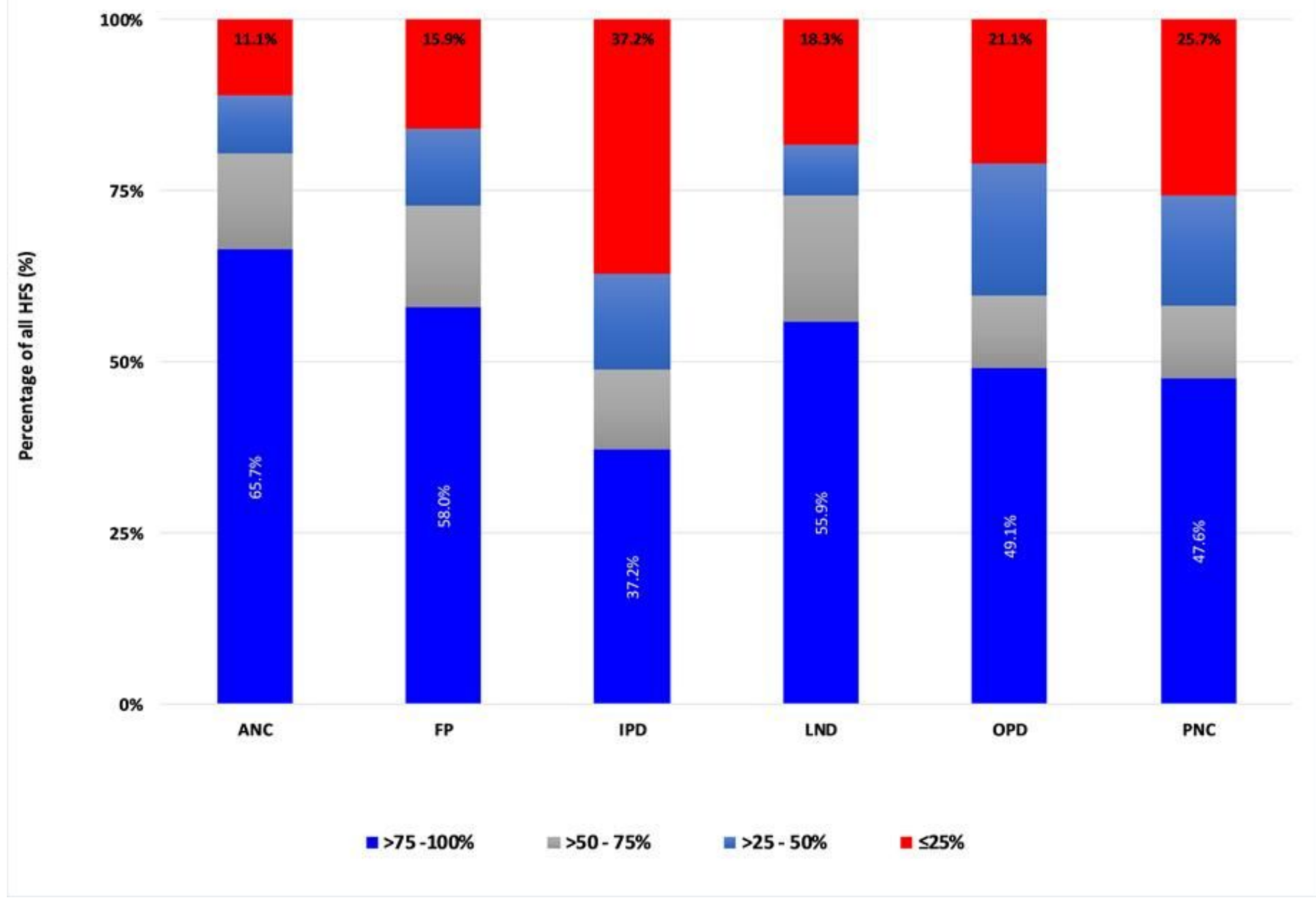

Figure 3

Tally-sheet availability levels by service area categorized into very high, high, average, and low windows. The percentages were calculated conditioning on the facilities providing the service 


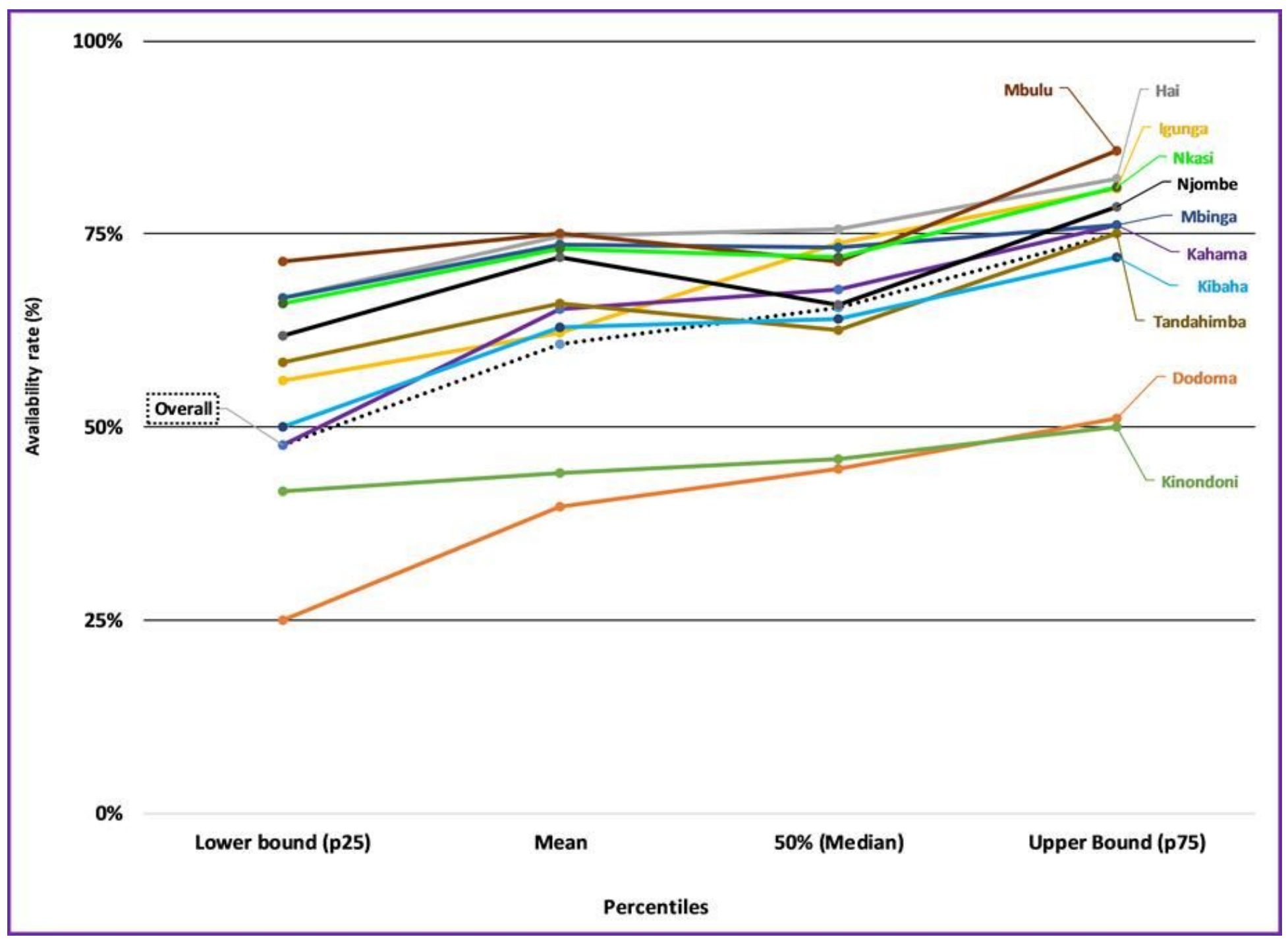

Figure 4

Median, mean and IQR of report form availability at district office (The dotted line indicates the overall status)

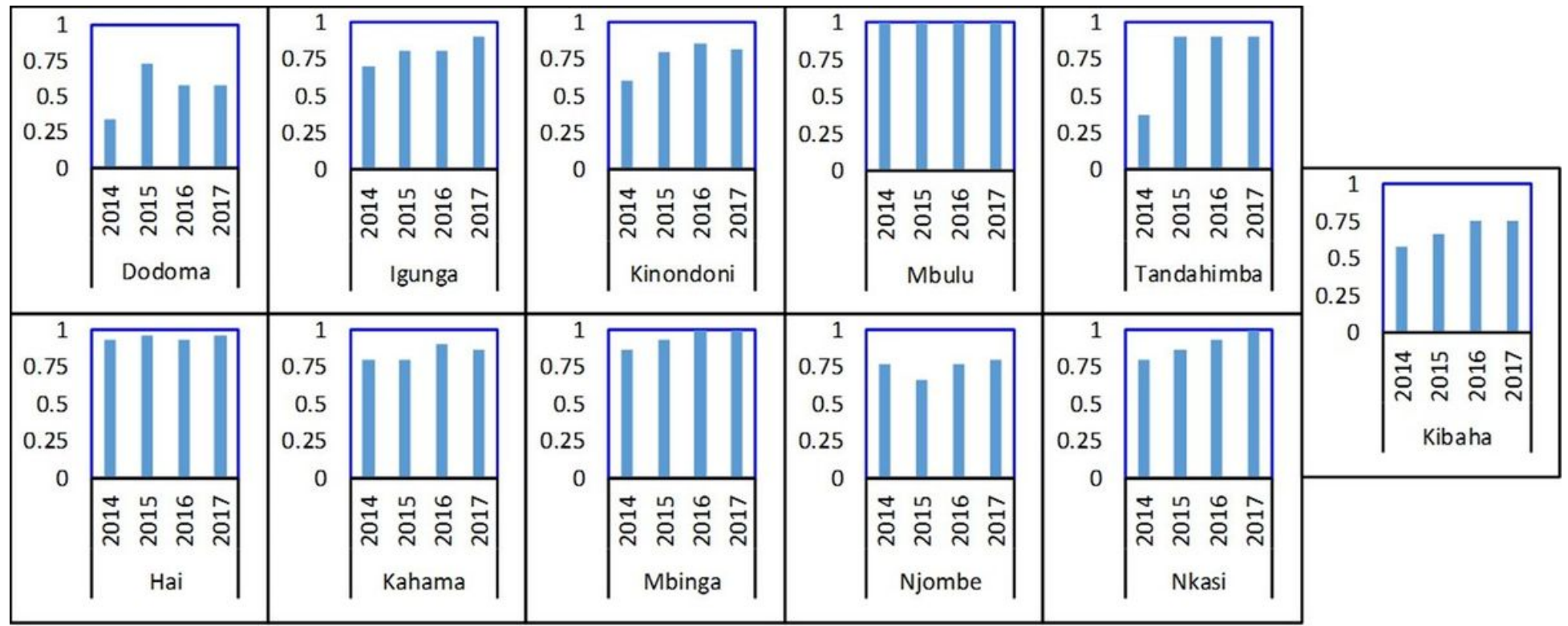


Figure 5

Report form availability rate at the district office 